\title{
Relationship between CEO Pay and Firm Performance: Evidences from Malaysia Listed Firms
}

\author{
${ }^{1}$ Shakerin Bin Ismail*, ${ }^{2}$ Natalie Vivienne Yabai, ${ }^{3}$ Low Joe Hahn \\ ${ }^{1,2,3}$ Faculty of Business and Information Science, UCSI University, Malaysia
}

\begin{abstract}
This study investigated the relationship between CEO pay and firm performance (return on asset, return on equity and profit margin) of 100 companies from the consumer product sector in Malaysia listed in Bursa Malaysia from 2006 to 2010. The research question for this study was will the payment of CEO affects the company's performance? Overall, most of the attestations results were found to have a relationship between CEO pay and firm performance. The correlations and regressions among the sub-variables of the firm performance and the CEO pay were found to be consistently positive ranging from weak positive to the strong positive.
\end{abstract}

Keywords: CEO Pay, Firm Performance, Agency Problem, Corporate Governance

\section{Introduction}

Every company needs Chief Executive Officers (CEO) to run the daily basis of the company's activities. CEO are appointed by the board of directors and they have the highest-level of executive position in a company who is responsible to create and to carry out the high-level strategies, corporate decision making, operations and resources of a company as well as acting as the middle person between the board of directors and the corporate management.

According to Douglas Mattern (2001), CEOs of major corporations made 42 times the average employees' pay in 1980. By 1990 that figure had increased to 85 times. In 2000, the average CEO salary reached an unbelievable 531 times that of the average employees' pay. Survey has already done on S\&P 500 US companies in the year of 2010. Average CEO Compensation was reported at \$11.4 million per year in 2010 (Connell, 2011). CEO pay has been a controversial topic. The public has been aware of this issue over the past decades and the High Pay Commission says that it has a "corrosive" impact over the economy (BBC, 2011). This issue affects efficiency, performance, and capabilities of the employees in the business world and also social gap appears due to CEO' pay whether is too high or even too low based on salary, bonuses such as short term reward, employee benefit, paid expenses, and insurance.

Some say CEO's pay affects the economy market and there is a difference among the CEOs which the pay is sometimes too high or too low. For example, in the United States, Vikram Pandit, the CEO of Citigroup received US\$1.75 million (Financial Post, 2012). Brian T. Moynihan, the CEO of Bank of American Corp, received US\$8,087,181 (Forbes, n.d.). The two previous amounts are much lesser than Jamie Dimon, who is the CEO of J.P Morgan Chase received \$18.7 million in compensation in 2012 (Huffington Post, 2013)

On the other hand, in Malaysia, Kaur (2013) from The Star reported that the CEO of CIMB Bank, Dato' Nazir Razak received RM10 million in remuneration, increased from RM8.7 million in 2011. Whereas the CEO of Genting, Tan Sri Lim Kok Thay, received RM86.5 million in 2007, the highest paid CEO in Malaysia (Fong, 2009). The CEO of IOI Corp, Tan Sri Lee Shin Cheng, received RM56.3 million in year 2010 (Yunus, 2012).

As CEO pay has become a very controversial public issue recently, Bebchuk and Fried (2004) have reported that CEO pay has not been closely tied to firm performance. Furthermore, according to Bebchuk and Grinstein (2005), they have suggested that executive pay has increased too high beyond the boundary that can be defined by the growth in firm size and performance observed from the year of 1993-2003.

From the observation held by Bebchuck and Grinstein (2005), it shows that while executive pay in public firms amounted to as much as $10 \%$ of corporate earnings in 2001-2003, only $20 \%$ of the increase in executive pay can be defined by the growth in firm size and performance. To response the idea from Bebchuck and Grinstein (2005), other people like Brandes, Goranova, and Hall (2008) have their own perception. They have argued that institutional investor, whose aggregate stock ownership share increased from $16 \%$ in 1965 to more than $61.3 \%$ in 2002. Moreover, as Brandes et al. (2008) has suggested that institutional investors perceive corporate executives to be excessively paid. Therefore, this issue will lead some institutional investors to abandon their traditional passive role and actively exercise their influence over CEO pay decisions in the corporate firms.

Problem Statement 


\section{The Importance of Corporate Governance}

In 2002, the CEO pay report regulations were introduced in United Kingdom (UK) to further strengthen the power of investors in relation to directors' pay. Further year on 2003, Australian securities Exchange (ASX) reinforced the corporate governance principles and responded to community concerns with a policy change that resulted in greater disclosure about CEO pay. The effectiveness of corporate governance affects the firm performance are totally undeniable. Having an efficient and effective monitoring skills in management will tend to make the firm perform better. The conflict of interest between manager and shareholder exist all the time while corporate governance is the remedies for this issue by motivating the manager to work in the interest of shareholders.

\section{CEO Pay as a Popular Issue in Business Range}

Some say CEO pay affects the economy market and there is a difference among the CEOs which the pay is sometimes too high or too low. The collapses of big corporation and financial institutions have heightened the awareness of the issue arising from the way in which CEO are paid. Bebchuk and Grinstein (2005) have suggested that executive pay has increased too high beyond levels that can be defined by the growth in firm size and performance observed from the year of 1993-2003. According to Yatim (2012), more than a decade CEO pay has attracted an unfavorable attention from practitioners, academics and media that have focused on the large amount of pay received by CEO. As a result of this issue, attention towards CEO pay has been subject to a regulation and also pay disclosures.

\section{Impact of CEO pay towards Firm Performance}

The impact of CEO pay towards firm performance brought a positive relationship. When the performance of a firm increases then the CEO pay would increase too. Mainly because of CEO pay and firm profitability are directly related to each other. Study that was done by Sigler (2011) mentioned that there is a positive and significant relationship between CEO pay and company performance measured by return on equity. However, in Malaysia there still less researcher performed a study based on this topic. Hence, in Malaysia there may be a result that is totally different from other research. Based on the uncertainty, there is a motivation to conduct this study in order to find out the true effects of CEO pay and firm performance.

\section{Research Questions}

Generally, the main questions that should be proposed is will the payment of CEO affect the company's performance? In addition, from the general question that is proposed, it could be subdivided into few research questions.

Below are the subdivide research questions:

Question 1: What is the relationship between CEO pay and profit margin?

Question 2: What is the relationship between CEO pay and ROE?

Question 3: What is the relationship between CEO pay and ROA?

\section{Research Objective}

The main objective of this research is to examine the relationship between the CEO pay and firm performance in public listed companies in Bursa Malaysia. The research will determine how would the CEO pay affects the firm performances of the companies. The research of this project will be based on 100 public listed companies in Bursa Malaysia based on the annual reports from the year of 2006-2010 in consumer product sector.

The main objectivity above can be sub-divided into each point:

Objective 1: To examine the relationship between CEO pay and profit margin

Objective 2: To examine the relationship between CEO pay and ROE

Objective 3: To examine the relationship between CEO pay and ROA

\section{Significance of study}

This study is based on previous study that is conducted in the US. The result in US study shows that the size of the firm appears to be a significant factor in determining the CEO pay (sigler, 2011). However, it may appear to be different results due to the difference of economic environment and government policy. This study examines the relationship between CEO pay and firm performance of 100 consumer product firms that are listed in Bursa Malaysia for the financial year of 2006-2010.

The significance of this study can be explained as follow. A study that was done previously majority in many-to-one relationship, where the CEO pay will be the dependent variable and board of director, CEO tenure, board independence, insider ownership and board size are the independent variables. In this research paper, we will examine a one-to-one relationship between firm performance and CEO pay. This study provides the latest dataset that can be used in analyzing the corporate governance in consumer products firm that 
is listed in Bursa Malaysia. In addition, the period for this study is from year 2006 to year 2010 which may provide an ideal setting on capturing the large economic cycle such as the sub-prime mortgage crisis that happened between years 2007-2010. This will provide us a great opportunity in analyzing and testing the impacts of different CEO pay on firm performance.

Besides that, this study is conducted because there are still less researchers who have conducted a study on a one-to-one relationship of CEO pay and firm performance in Malaysia. Our study actually based on previous research that was done in US and China. One of the research papers in US shows that the size of the firm appears to be a significant factor in determining the CEO pay (Sigler, 2011). One of the reports in China says that "executive pay in public firms amounted to as much as 10\% of corporate earnings in 2001-2003; only $20 \%$ of the increase in executive pay could be explained by the growth in firm size and performance." (Shin and Seo, 2010).

It was found that mostly this study was done in western countries but lesser in Asia. Unlike other countries like US and China, Malaysia provides an excellent advantage in conducting corporate governance research because of the mixed-economic system that consist of market-based and control-based system. Furthermore, our study might be contributed to the marketeers especially in consumer products sector companies since there are few numbers of researchers that had done their study on this area of business. For those undergraduate students that are interested in doing this study but in different sectors might be good and useful as a references as well. Besides, shareholders of a particular company will also find this research useful since it helps to explain the reason behind the high pay of CEO.

\section{Literature Review}

The development of this study is based on three related strands of literature review, namely, the literature on the conflict of interest of principal and agent (theory of agency), literature on corporate governance and the relationship of CEO pay and performance.

Figure 1: Conceptual Framework

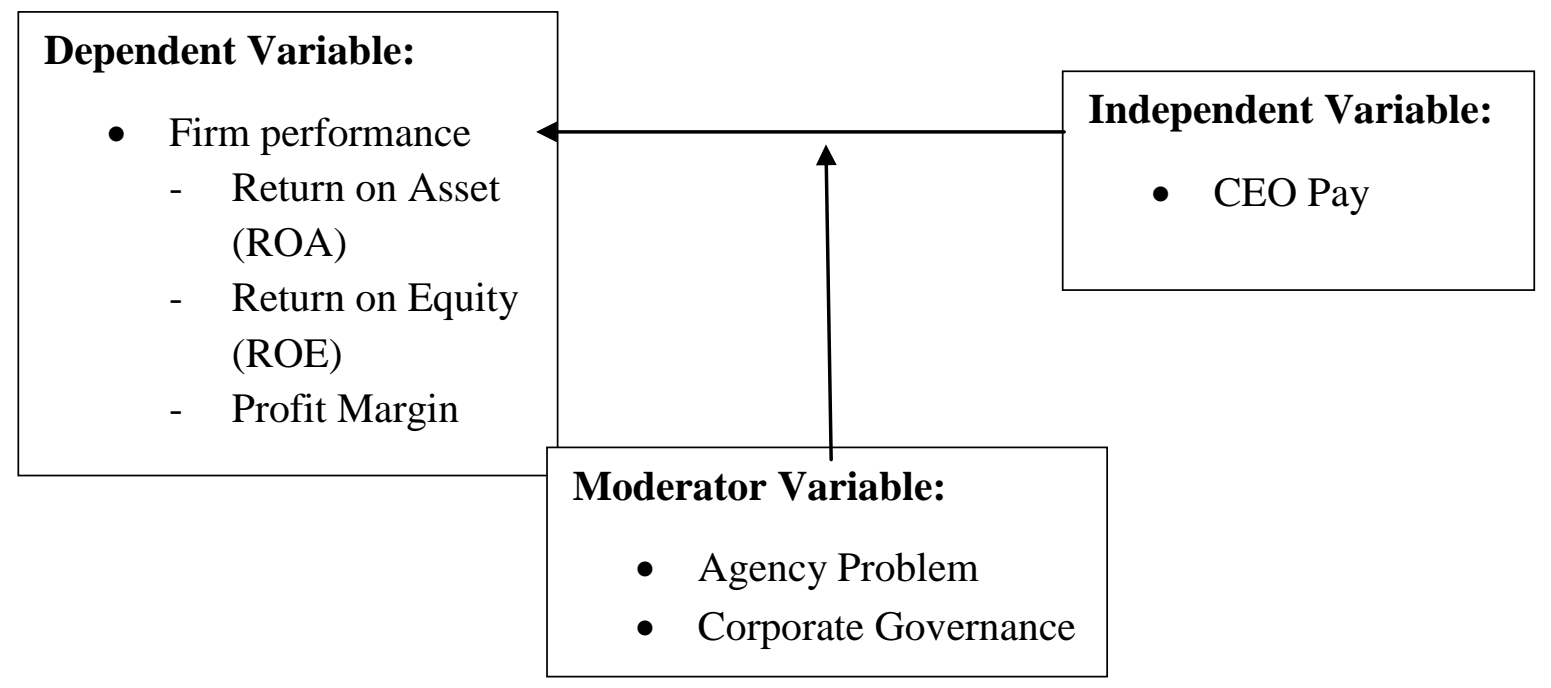

\section{Dependent and Independent Variables CEO pay and firm performance}

In recent years, there is a widely held belief that top executives are overpaid (Gomez-Mejia, 1994) and CEO compensation has attracted the widespread of attention and has become one of the focus issue in corporate governance (Felton, 2004). It shows that the increasing payment in CEO pay has numerous effects over two decades in the business field. According to Bebchuk and Fried (2004), critics have voiced concerns about CEO pay has not been closely tied to the firm performance. Some studies stated that CEO pay is not always beneficial. Devers et al. (2007) has reported that the stock-based pay may encourage CEO to engage in negative behavior or so called fraud. Since there is a heavy usage of stock-based pay which provides CEOs with perverse incentives to maximize their private wealth, then CEO may have more advantage on boosting their accounting earning which is sometimes can be illegal. Other reason, CEO can control the firm and hence can force to agree to the CEO's desired pay. 
Haugen and Senbet (1981), Agrawal and Mandelker (1989), Lewellen, Loderer and Martin (1987] and Abowd (1990) has proposed that the type of behavior may be curbed is through linking the CEO pay to the firm performance. Pay components such as bonuses, restricted stock and stock options may encourage managers to carry out the wishes of company owners by tying payouts directly to firm performance. However, Sigler (2011) argued that the pay components like cash bonus, incentives plans, stock options and restricted stock awards may also attract some CEO to engage into activities that produces problems for the firm. Rewarding cash bonuses clearly shows an advantage for executives to do an undesired behavior. The cash bonus that is tied to the accounting numbers may motivate $\mathrm{CEO}$ to manipulate the timing of revenues and expenses to maximize the pay out for them. Sigler (2011) also mentioned that it may focused on the short term performance which may be harmful to the long term health of the firm.

Some study says that aligning shareholder and management interests may also be accomplished through ownership of company stock by management which essentially makes company managers owners themselves. Jensen and Meckling (1976) demonstrated the importance of aligning CEO pay with company performance. They documented that an executive with less than sole ownership of the firm have an incentive to take actions that reduce the firm value. Another study that was done by Leonard (1990) says that long term incentives plans are associated with greater increases in ROE than in those firms without long term incentive plans.

Pay to performance sensitivity generally has been measured in a lot of studies before. Pay to performance sensitivity is defined as the wealth associated with a dollar change in the wealth of shareholders or the dollar change in the CEO's pay. Basically the idea is to encourage the CEO to act in the shareholders interest. Through this idea, firm that depends on the provision of incentive compensation in the competition of capital markets will make the firm stand strong and survived. Firms that failed to compensate managers in this way may face a higher cost and hence will not compete successfully with firms whose managers that act in accordance to the shareholders interest. According to Hengartner (2006), pay performance sensitivity is typically measured by tracking current changes of firm financial performance (typically total shareholder return) to changes in CEO compensation or wealth.

According to the test that was done by Lewellen, Loderer, Martin and Blum [1992] and Sigler and Haley (1995), they found that CEO pay and firm performance has a positive relationship. Besides, there is a significant relationship between firm performance and the percentage of company common stock owned by the CEO (Sigler and Haley, 1995). From the results that appears to be significant it can be concluded that CEO pay are used to align with the shareholders interest and thereby reduce the company agency cost. Besides, Murphy (1985) and Coughlin and Schmidt (1985) also found a one per cent increase in CEO pay may increase the firm value of 10 per cent. Their study was comparable with Jensen and Murphy (1990) estimated a positive and significant relationship between CEO pay and shareholders wealth, finding that CEOs receive an extra USD2.59 in pay for every USD1000 increase in company value. They also found that salary and bonus (as opposed to wealth) changes only $2.2 \phi$ per $\$ 1,000$ change in shareholder wealth, and total pay changes by about $3.3 \notin$ per $\$ 1,000$ change in shareholder wealth. It was suggested that this link between pay and performance, while statistically significant, is too weak to provide proper incentives to the CEO. Moreover, the results was further demonstrated that the incentives generated by stock ownership are large relative to direct pay incentives.

It is also argued that other authors note that the existing empirical work ignore certain features of compensation contracts. Top executives actually are involved in multi-year relationships with their firms, and thus one should look at the long-term, dynamic relationship of compensation and performance to find the complete pay to performance link (Boschen and Smith, 1995). In fact, study that is done by Boschen and Smith are found to be more stronger pay to performance link than the study that was done by Jensen and Murphy (1990) by using the similar technique. In addition, Aggarwal and Samwick (1999) also tested and predicted that the relationship between compensation and performance should increase with the variance in firm performance. The prediction and note that when the account for firm performance varied, the pay-performance link become more significant than Jensen and Murphy test.

Nevertheless, Smyth, Boyles and Peseau (1975) and Hirschey and Pappas (1981) argued that in rate of return regulated environment, the role of compensation is to provide incentives for sales maximization rather than profit maximization. Sales growth is shown to be significantly linked to executive compensation (Kato and Long, 2004) and that Chinese executives are penalized for making negative profit although they are neither penalized for declining profit nor rewarded for rising profit insofar as it is positive. Kato and Long (2004) also found that in China the ownership structure on China's listed firms has important effects on pay-performance link in these firms. Firstly, state of ownership of China's listed firms is weakening pay-performance link for top 
managers and thus making China's listed firms less effective in solving agency problem. Secondly, the effect of the existence of both direct government ownership through state share and indirect government ownership through legal person shares and indirect ownership of listed firms by the state have weaken pay-performance link more than direct state ownership. Lastly, corporate governance reform measures such as the promotion of independent directorship and the separation of the CEO position from the board chairmanship are ineffective in making pay-performance link stronger. Overall, it shows that pay-performance has a general lack of consensus on the precise relationship.

Ozkan (2007) has reported that performance has a positive but insignificant impact on director pay. It is argued that larger firms may employ better qualified and better-paid managers. In addition, director ownership may lead to greater managerial discretion and hence potentially play an important role in determining director pay.

\section{Agency Problem}

\section{Moderator variables}

Agency is defined as the relationship between two parties, where one of the parties will act as a principal and the other party as an agent and this agent is obligated to represent the principal in transactions with another third party. Agency relationship will formed when the principal hires an agent to perform a duty of service or a transaction on behalf of the principal. Scholars had used agency theory in accounting (e.g., Demski and Fetham, 1978), economics (e.g., Spence and Zeckhauser, 1971), finance (e.g., Fama, 1980), marketing (e.g., Basu, Lal, Srinivasam and Staelin, 1985), political science (e.g., Mitnick, 1986), organizational behavior (e.g., Eisenhardt, 1985, 1988; Kosnik, 1987) and sociology (e.g., Eccles, 1985; White, 1985). Most of the researchers found that in agency relationship there is always a conflict between managers' interest and shareholders' interest.

A study done by Jensen and Meckling (1976) discussed about the conflicts of interest that exist between shareholders and managers. Normally, the agent has the authority to make a decision that is approved by the principal. Another theory mentioned by Fathers of Economics, Adam Smith's (1776), the conflict of interest exist between agency relationship came from the ownership structure of the firm which creates mismanagement and hence it allows "negligence of their own servant"; firm failed to control.

"The directors of such companies, however, being the managers rather of other people's money than of their own, it cannot well be expected, that they should watch over it with the same anxious vigilance with which the partners in a private co-partner frequently watch over their own. Like the stewards of a rich man, they are fit to consider attention to small matters as not for their masteries honor, and very easily give themselves a dispensation from having it. Negligence and profusion, therefore, must always prevail, more or less, in the management of the affairs of such a company."

Adam Smith (1776)

In addition, since the mismanagement bring to the negligence of their own servant, then, we should give a closer navigation on control. Control is defined as the key which gives greater influence on the relationship between the principal and agent (Berle and Means, 1932). Berle and Means (1932) found that there is a different between the separation of ownership and management and the separation of ownership and control. In other words, management are held to be the responsible to implement a strong and strictly adhere corporation that owns a great power of voting rights and stock. Company act 1965 required management to implement rules for corporation that majority shareholders must comprise of $75 \%$ so that they can manage or amend the articles of association. The separation of ownership and control leads to the diverging of interest between principals and ultimate agents which in long term view will detriment the health of firm as a whole economy.

In business environment, agency relationship is mainly between stockholders and managers and also between debt holders and stockholders. The existence of such relationship has not always been so pleasant mainly is because of the existence of conflict of interest. The conflict can bring an impact towards corporate governance and also ethical decision of the management.

When an agency is created this in turn will give rise to agency cost. Such cost exist due to the cost of maintaining an effective and a healthy agency relationship. Offering an extra incentives or bonuses will motivate the management to act based on the interest of shareholders. Based on a few studies that were done before, the relationship of agency can be controlled through linking the pay of CEO such as bonuses, restricted stock and stock options to the performance of the firm (Haugen and Senbet, 1981; Agrawal and Mandelker, 1989; Lewellen, Loderer and Martin, 1987; Abowd, 1990). However, the conflict between principal and agent is still remained as an issue among the firms. 
Jensen and Meckling, (1976) argued that when managers make efforts to increase the performance of the firm they cannot get 100 per cent benefit from the firm's profit. This is because they do not have 100 per cent ownership of the firm. In this case, whenever there is a financial demand or decision making, the manager would not just consider about the interest of the shareholder but their own interest need to be considered as well. It is logic to think that both the principal and agents is trying to maximize their own interest. Hence, conflicts of interest and no direct observation from principal towards agent will lead to ethics issue, which will give rise to an extra cost. They also suggested that this conflict can be minimized by giving manager ownership options in form of stock options, perquisites and incentives so far well presented in the literature of corporate finance by Jensen and Meckling (1976), Watts and Zinmmerman (1978) and Miller and Rock (1985).

The pay components may encourage managers to carry out the interest of shareholders and work even harder to increase profitability and values of the firms. Besides that, previous studies mentioned that agency theory had suggested a number of indirect ways to lessen down the agency cost. These include the internal governance structures such as smaller boards (Yermack, 1996), a higher degree of board independence (Rosenstein and Wyatt, 1990) and CEO ownership (McConnell and Servaes, 1990). As a major explanation for CEO pay (e.g., Baker et al., 1988; Jensen and Murphy, 1990), agency theory has been challenged by the corporate compensation practices (Mintzberg, 2009) and it has also been criticize for its inability of cross-country difference (Haubrich and Popova, 1998; Bruce et al., 2005; Filatotchev and Allcock, 2010).

Nevertheless, Jensen and Ruback (1983) stated that the manager may use the excessive cash flow that is available in the firm for their own use by investing them in certain projects, which might not bring positive effect or non-productive for maximizing the profit and wealth of shareholders. There is a better way of utilizing the excessive cash flow by giving out dividend to the company's shareholders rather than to invest into another project. Monitoring skills from the managers is very important to make sure the manager will work at the best interest of the shareholders. However, in order to have an effective monitoring skills, cost of monitoring would incurred as well. In another words, the greater the monitoring skills, the higher the cost would be for the manager. Lubatkin and Chatterjee (1994) said that by increasing the debt to equity ratio, the shareholder of the firm will be able to ensure that the managers are working at their best interest and running business more efficiently and the excess cash flows generated from business would be distribute to the investor as a return after the repayments of debts, and avoiding negative net present value (NPV) projects. The main two bodies of the corporate governance are the lenders and shareholders. So, if the managers failed to serve the shareholder aim and also the debts holder obligation the manager will have themselves replaced to whom that can serves better in maximizing shareholder wealth and meet debts holder obligation.

Myers and Majluf (1984) stated that the management are most likely to be more informed than the firm's potential investors about the firm activities, assets and value of the firm. From here, asymmetry information are known to be existed. This is because firms are tend to issue debts due to the asymmetry information (if they issue shares, the share price would fall). According to the data that was collected by Myers and Majluf (1984), current shareholders of the firm would prefer debts financing method rather than equity financing in order to avoid stock price issue. Hence, the higher managerial ownership firm, the higher leverage the manager would prefer in order to serves the best interest of the shareholders.

Berle and Means (1932) discussed about the potential conflict between managers and stockholders of a diffusely owned company. Meaning, a company that have a larger amount of shareholders but hold lesser shares which bring a potential conflict of interest. The managers may undertake decision or projects that are not value-adding but rather to create benefit for manager such as consumption of perquisites, sales growth, empire building, shirking, and managerial entrenchment. The management ultimately will be responsible for implementing a corporation owns a majority of the voting stock while the remainder is widely diffused; control and part ownership are in their hands. Baumol (1959) stated that managers maximize sales but not profits. In his theory, sales growth correlates positively with managerial compensation. Simon (1959) and Baumol (1967) both stated that managers seek to provide a minimum level of satisfaction to shareholder. Conversely, the profits are sacrificed to increase the utility of management. Williamson (1964) sees managers as maximizing a function of profits and a set of variables that generally correlate with size.

The role of individual performance against the agency controls is to gain the individual effort and task performance. If there is a chance for individual effort, then agency control should have equivalent effects across all individuals. On the other hand, if there is no chance, agency control should have differing effects between individuals. 
In order to gain the opportunity between individuals, there are incentives alignments of performance and monitoring on performance. As Conyon and Parks (1990), Dalton, Daily, Certo, and Roengpitya (2003) and Dalton, Daily, Ellstrand, and Johnson (1998) have suggested that the two effects will suggest (a) the default agent behavior is not one of opportunism and/or (b) that both incentive alignment and monitoring are not straightforward mechanisms for controlling agent performance. In addition, the individuals' experience may affect feelings of control over whether they will meet the performance requirements or not. Thus, those who have more experience may have more effort because their effort will be late to the required outcomes.

In human nature, there are five individual personalities' differences. The five personality factors are agreeableness, conscientiousness, extraversion, neuroticism, and openness to experience. Among the five factors, conscientiousness is the greatest impact on individual performance. Conscientiousness will measure in achievements orientations, independent and great consideration.

From the performance perspective, if the agency controls have a little effect on conscientiousness the performance will be low. On the other hand, if the agency controls have a high conscientiousness, which implies to individual, this will effect on high performance with or without incentives or monitoring.

In agency theory problem, the important factor here is monitoring. Monitoring from shareholders will affect the decision making of the management. Management acts as an agent on the behalf of shareholder (principal) and hence the decision made by manager should be equilibrium of maximizing managerial benefits and also maximizing shareholder wealth. By monitoring, both can reach a decision that would optimize the equilibrium and ultimately increase the value of the firm.

\section{Corporate Governance}

Corporate governance has received increasing emphasis both in practice and in academic research (Ramsay Report 2001; Sarbanes-Oxley 2002; Bebchuk and Cohen 2004). This emphasis is due, in part, to the prevalence of highly publicized and mistakes of financial reporting frauds such as Enron, Worldcom, Adelphia, and Parmalat, an unprecedented number of earnings restatements (Palmrose and Scholz 2002; Larcker et. al. 2004) and claims of blatant earnings manipulation by corporate management (Krugman 2002). The importance of the board of directors (BOD) arises as a result of the dispersion of ownership in today's modern corporations, which rely heavily on the external sources of capital. Thus, the owners of the firm are no longer the ones responsible for controlling the direction and the day to day operation of the firm. Instead, the daily operations of the firm are rather controlled by a team of professional managers who, at best, own a negligible amount of equity.

Based on the evidence from Bauer, R., Guenster, N. \& Otten, R. (2004), it shows that there is substantial differences are found between UK market and the Eurozone market on the relationship between corporate governance and firm value as well as equity is combined. The results indicates that UK market is still adjusting and in the long-run, the excess return of corporate governance should be translated into a higher firm valuation and better-governed firms. This results is in line with prior empirical research discussed above, which also demonstrated that the lower the governance standards, the stronger the relationship between governance and firm value.

Based on the previous research done by Pearson, O. S. (2006), the result based on regression analysis indicate that both the independence and effectiveness of the BOD can help to reduce the likelihood of the non-financial reporting fraud. Pearson, O. S. (2006) shows that the likelihood of non-financial reporting fraud is lower if the BOD has larger proportion of outside independent directors, the CEO and BOD chairman are not the same person, BOD size is smaller and the profitability is higher. The result regarding outside directors supports the recent regulatory reform of corporate governance which requires majority of independent directors on the board. The BOD size result indicates that smaller board size is likely to be more effective in monitoring management.

Several studies have provide evidences on linking good corporate governance with better firm's performance (Brickley et al, 1994; Byrd and Hickman, 1992; Chung,Wright and Kedial, 2003; Hossain, Cahan and Adams, 2000; Lee, Rangan and Davidson, 1992; Rosenstein and Wyatt, 1990; Weisbach, 1988). On the flipped side of the opinion, good corporate governance can improves company performance. Some other researchers have demonstrated negative link between corporate governance and company performance (Bathala and Rao, 1995; Hutchinson, 2002). Furthermore, there is also different studies have found no relationship between good corporate governance and firm performance (Park and Shin, 2003; Prevost, Rao and Hossain, 2002; Young, 2003). These various results can be explained by many reasons. Some have claimed that the problem is related 
to the use of either publicly available data or survey data as these causes are usually limited in scope. It has also been demonstrated that the nature of performance measures restrict the use of accounting based measures such as return on assets (ROA), return on equity (ROE), return on capital employed (ROCE), earning per share (EPS), or restrictive use of market based measures (such as market value of equities) could also favour this contradiction (Gani and Jermias, 2006).

Additionally, it has been debated that the "theoretical and empirical literature in corporate governance consider to be the link between corporate performance and ownership or structure of boards of directors mostly using only two of these variables at a time" (Krivogorsky, 2006). For example, Hermalin and Weisbach (1991) conducted a research on the correlation between board composition and firm performance, whiles Demsetz and Villalonga (2001) studied the relationship between managerial ownership and company performance. According to Coleman (2007), to solve some of the above mentioned problems, it is important to examine corporate governance and its correlation with firm performance using a multivariate approach.

The recent financial crisis has raised serious criticism particularly regarding corporate governance on executive compensation (Fahlenbrach and Stulz, 2011; Bebchuck et al., 2010; Kirkpatrick, 2009). It has been often argued that remuneration and incentive systems have played a key role in influencing risk taking behaviors of managers. The positive link between compensation and risk has remained strong throughout recent events based on the evidenced by several recent empirical studies (e.g., Adams, 2012; Chesney et al., 2012; Bolton et al., 2011; Balachandran et al., 2010).

In 2003, the Australian Securities Exchange (ASX) reinforced the corporate governance principles and responded to community concerns with a policy change that has resulted in greater disclosure about CEO remuneration (Yatim, 2012). Yatim, (2012) also state that since May 2003, listed companies have been required to make full disclosure about the remuneration packages of newly appointed CEOs and such disclosure includes information about the components of pay package which might govern the actions of the CEO and drive levels of performance.

Corporate governance can be seen as a vital contribution factor to a firm's performance and value but in fact it is yet to be defined. As several previous researches show different results on the effect of corporate governance on firm performance where it could be either positively, negatively or no significant relation. There is also research done in the past that shows corporate governance could affect the CEO compensation and as an indirect result could or could not affect the firm performance.

\section{Research hypotheses}

An empirical study that was done before on the pay-performance relationship shows different results and findings. From an agency theory perspective, the link between firm performance and CEO pay should provide an important incentive for corporate success. An existing empirical evidence that was studied in United State shows a weak but significant positive relationship between performance and CEO pay (e.g., Jensen and Murphy, 1990; Murphy, 1999; Core et al., 1999). By reducing agency cost, aligning managerial interest with shareholders gives a positive relationship of pay-performance with the role played by compensation. Lewellen, Loderer, Martin and Blum [1992], state that those companies which pay better perform better. On the other hand, there are certain studies that show a negative pay performance relationship. Core $e t$ al., (1999) report that excess CEO compensation has a negative association with subsequent stock returns as well as operating performance. Similarly, Brick et al., (2006) also find that there is a negative relationship between excess director compensation and firm performance. Based on the analysis of studies that was done before majority of it stated that pay-performance can be link to a positive relationship. A study that was done by Sigler (2011), shows that the company performance variable, ROE, has a positive and significant coefficient. This is consistent with the premise that CEO pay is paid in relation to how the company performs. Yatim (2012) performed a study in Malaysia says that the results shows that director remuneration is significantly related to ROA. Profit margin is defined as the net profit divided by the revenue. So, we believe that in Malaysia, there will be a significant relationship between CEO pay and ROA, ROE; and profit margin. Therefore, the study proposes the following hypothesis.

Hypothesis 1

$H_{0}$ : There is no significant relationship between CEO pay and ROA

$H_{A}$ : There is a significant relationship between CEO pay and ROA 
Hypothesis 2

$H_{0}$ : There is no significant relationship between CEO pay and ROE.

$H_{A}$ : There is a significant relationship between CEO pay and ROE.

Hypothesis 3

$H_{0}$ : There is no significant relationship between $C E O$ pay and profit margin.

$H_{A}$ : There is a significant relationship between $C E O$ pay and profit margin.

Note: $\mathrm{H}_{0}$ refers to null hypothesis; $\mathrm{H}_{\mathrm{A}}$ refers to alternative hypothesis.

\section{Research Methodology}

This chapter consists of the information related to research design, research location, population and sampling method, data collection, instrumentation, variable measurement and data analysis.

\section{Research Design}

In this study, data analysis will be performed by using SPSS statistics and EViews 7.0 software. These are the software that provides the tools for data analysis. For example statistical, forecasting, regression and other modelling tools. The information will be shown in table forms for interpretation of data analysis.

This is a study of a relationship between CEO pay and firm performance in public listed companies in Bursa Malaysia. We conducted this study with a sample of 100 consumer product firms from the year of 2006 to 2010. This research is a quantitative research method in which the research will be done based on primary data. Data will be collected from journals, companies' financial statements, and online articles. Hypothesis testing is used to test on how each variable affects one another. In addition, the research study comprises Pearson correlation analysis and regression analysis to determine the relationship between CEO pay and firm performance (ROA, ROE and profit margin).

\section{Research sampling}

In this paper, data will be analysed on the companies incorporated in Malaysia which are listed in Bursa Malaysia for the financial period from year 2006 to 2010. In Bursa Malaysia, listed firms can be categorised into several sectors including consumer products, industrial products, trading/services, construction, technology, properties, plantation, financial and regulated utilities. Instead of taking the whole listed firms as published in Bursa Malaysia, we will only take consumer product sector with a total of 100 companies to be used as sample to conduct our studies. This is because we wanted to look into a more specific sector to study instead of taking several sectors that may lead to a more general study in this area.

\section{Sample Selection}

Table 3.2.1: Sample firms

\begin{tabular}{lll}
\hline Sectors & Sample & Percentage represents \\
\hline \hline $\begin{array}{l}\text { Consumer Products } \\
\text { Total Firms }\end{array}$ & 100 & $76.34 \%$ \\
\hline \hline
\end{tabular}

Notes: Total firms in each sector are taken from the financial reporting year 2006 to 2010.

Our objective of this research is to study the relationship between CEO pay and firms' performance, we will obtain the information of CEO pay from the company's statement of financial performance, whereas the firm's performance will be obtained from the statement of comprehensive income for a 5-year period from the year of 2006 to 2010. This period consists of pre-financial crisis, during the financial crisis and post-financial crisis period, we choose this period is to see whether the financial crisis affected the CEO's pay and firm's performance. Besides that, we chose consumer product sector is because it is the second largest sectors in Malaysia that are listed in Bursa Malaysia (Star Newspaper, $5^{\text {th }}$ June 2013). All these information will be collected from the listed firms' annual report as published in the website of Bursa Malaysia.

\section{Variable Measurement}

CEO's Remuneration

Malaysian companies' boards of directors consist of executive non-independent (CEO or Managing Executive Director), non-independent executive directors, independent non-executive directors and institutional investor. In this part, we will look into the executive director remuneration. In this research, all the CEO remuneration 
data we used are obtained from firm annual reports starting from accounting financial year 2006 to 2010. The CEO remuneration consists of basic salary, bonus, allowances, fees and pension benefits.

In this study objective, we measure the total CEO pay from the total of all cash remuneration for executive director for the financial reporting year 2006 to 2010. The average level of CEO pay is described as total cash pay (known as salaries and other direct compensation) where total direct compensation is total salary, bonus, and share options.

\section{Firms' Performance}

We decided to use profitability ratio, which includes return on assets (ROA), return on equity (ROE) and profit margin to measure the firms' performance.

According to Dong and Ozkan (2007), there is a relationship between the company performance and CEO pay. CEO pay is needed to solve the agency theory that arises in most of the companies. Meaning to say, giving the right incentive to the director is to help align the interest of managers and shareholder. Return on asset (ROA), return on equity (ROE) and profit margin are also considered as the profitability ratio-based performance measure. According to Doucouliagos et al. (2007), agency theory is the aim of compensation contracts to reward agent in such a way that they strive to maximize firm performance and shareholders' wealth.

Return on asset (ROA) is the ratio of net income before extraordinary items to total assets. Return on assets indicates the number of cents earned on each dollar of assets. Thus, the higher the value of ROA, the higher the profitability of a business. However, this ratio should only be used to compare companies in the same industry. This is because certain companies in other industries are not asset-sensitive, meaning that they need expensive plant and equipment to generate income for their business compared to others. Naturally, their ROA will be lower than those whose companies are asset-sensitive. This is why in our research we conducted in only one industry, which is the consumer product industry.

Return on equity (ROE) is the ratio of net income before extraordinary items to shareholders' equity. Return on equity is an important measure to measure the profitability of a firm. The higher the values of the ROE, the higher the efficiency in generating income on new investment of the firm.

Profit margin is defined as the net profit divided by the revenue. The ratio defines how much of a company's revenues are kept as net income. Profit margin is very useful when comparing companies in the same industries. A high profit margin shows a more profitable company that has a better control over its expenses.

\section{Regression Framework}

The model used to test the hypotheses is as follow:

Equation 1: The relationship between CEO pay and ROA

$(\mathrm{ROA}) \mathrm{t}=\alpha+\beta \mathrm{LOG}\left(\mathrm{CEO} \_\mathrm{PAY}\right) \mathrm{t}$

This equation represents the first hypothesis that had been done in chapter 1. This equation is to examine any relationship of CEO pay and ROA holding alpha as a constant value.

Equation 2: The relationship between CEO pay and ROE

$(\mathrm{ROE}) \mathrm{t}=\alpha+\beta \mathrm{LOG}\left(\mathrm{CEO} \_\mathrm{PAY}\right) \mathrm{t}$

Hypothesis 2 represents the equation above which is to analyze the relationship of CEO pay and ROE whether it is a significant or non-significant relationship, holding alpha to be a constant amount.

Equation 3: The relationship between CEO pay and profit margin

$(\mathrm{PM}) \mathrm{t}=\alpha+\beta \mathrm{LOG}\left(\mathrm{CEO} \_\mathrm{PAY}\right) \mathrm{t}$

To test the firm performance we use profit margin as the third hypothesis and also in our equation because it is related to the revenue and net profit of the firm, holding alpha value as constant.

Table 3.3.3: Variable Definition

\begin{tabular}{|c|c|}
\hline \multirow{2}{*}{\multicolumn{2}{|c|}{$\begin{array}{l}\text { Variables } \\
\text { Dependent }\end{array}$}} \\
\hline & \\
\hline$(\mathrm{ROA}) \mathrm{t}$ & $=$ the firm's return on assets; \\
\hline$(\mathrm{ROE}) \mathrm{t}$ & $=$ the firm's return on equity; \\
\hline$(\mathrm{PM}) \mathrm{t}$ & $=$ the firm's profit margin. \\
\hline Independent & \\
\hline$\beta L O G\left(C E O \_P A Y\right) t$ & $=$ the natural logarithm of CEO pay for the firm; \\
\hline
\end{tabular}




\section{Data collection}

The study of this paper will be on the observation of 100 consumer product sector listed in the website of Bursa Malaysia. The data collection from the firms' annual report from year 2006-2010 of these 100 companies are downloaded from Bursa Malaysia website.

\section{Data analysis method}

In order to study the relationship between CEO pay and firms' performance, the data collected from the Bursa Malaysia website will be analyzed by using SPSS statistics software and EViews 7.0. These are the software that provides the tools for data analysis. For example statistical, forecasting, regression and other modelling tools. The information will be shown in table forms for interpreting the data analysis.

There are 3 different results of each test which contains:

\section{Descriptive statistic}

Descriptive statistics are used to describe basic features of the data in a study. It is also to analyze the quantitative analysis of data for measuring the outcome. It used to eliminate all secondary data and highlights the main statistics. Descriptive statistics provides measurement of consistency summary that useful for the comparison and helpful for the probability of future planning. It presents the data in units and also in each single unit that will fall into a simple summary. In this study, we will analyze the descriptive statistic using EViews 7.0 software.

\section{Pearson Correlation}

Correlation coefficient is a single number that describes the degree of relationship between two variables. The correlation coefficient is the range between -1 and +1 . Perfect positive correlation or a correlation coefficient +1 implies that as one security moves, one variable moves up or down, the other security will move in lockstep in the same direction. Perfect negative correlation or a correlation coefficient -1 means that if one security moves in either direction the security that is perfectly negatively correlated will move in the opposite direction. If the correlation coefficient is 0 , it means no correlation of the securities. Therefore, in our study we will use SPSS software to analyze the correlation coefficient.

\section{Regression Analysis}

Regression Analysis is a statistical measure that attempts to determine the strength of the relationship between one dependent variable (Y) and one or more series of other changing variables known as independent variables (X). For this research, we will study on the dependent variable, which is CEO pay and the independent variable, firm's performance. For this analysis, we will be using EViews 7.0 software to analyze our regression model.

Besides the three types of analysis above, we are also using financial term like ROA, ROE and PM to evaluate a company's performance. Below are the explanation of each term:

\section{Return on Assets}

Return on assets is an indicator of the profitability of a company in relative to its total assets. It gives an idea on how efficient the management is at using its assets to generate income. Return on assets is calculated by dividing the company's annual earnings by its total assets, it is displayed as a percentage.

The formula for return on assets is

$$
=\frac{\text { Net income }}{\text { Total assets }}
$$

\section{Return on Equity}

Return on equity is the amount of net income returned as a percentage of shareholders equity. Return on equity measures a corporate's profitability by showing the profit of the company generated by the money invested by the shareholders.

The formula for return on equity is

$$
=\frac{\text { Net income }}{\text { Shareholder's equity }}
$$

\section{Profit Margin}

A ratio of profitability is calculated by the net income over the revenues, or net profits over the sales. Profit margin measures how much out of every dollar of sales a company keeps in earnings. It is very useful when used to compare among companies in similar industries. A higher profit margin indicates a more 
profitable company that has better control over its costs compared to its competitors. Profit margin is displayed as a percentage value.

The formula for profit margin is

$$
=\frac{\text { Net income }}{\text { Total Revenue }}
$$

\section{Analysis And Discussion}

This chapter consist of all the analysis that was discussed in chapter 3 which are descriptive analysis, Pearson correlation analysis and regression analysis.

\section{Descriptive Analysis}

Table 4.1 shows the results of descriptive statistics for the firm performance (dependent variable) and CEO pay (independent variable) over the years of 2006 till 2010 that are listed in Bursa Malaysia consumer products sectors. The table summarizes the independent variable of LOG_CEOpay_t which has a mean of 14.02 that has a similar amount of RM1,836,799. This can be reported that within 2006 till 2010 the CEO pay of a 100 companies that are listed under consumer products in Bursa Malaysia has a mean of RM 1,836,799. The median of LOG_CEOpay_t reported to be on 14.11 which is equal to the pay of RM 1,347,000. Besides that, the maximum amount of the independent variable is 16.99 which is equivalent to RM 24 million while the minimum amount is 9.47 which shows the lowest of CEO pay is RM 13,000. In this descriptive analysis, standard deviation also was tested for every variables. Standard deviation is to show how much variation from the average does exist. Table 4.1 shows the standard deviation for LOG_CEOpay_t is 0.984175 which is equal to RM1,957,521.

In the table, it also summarizes the amount of dependent variable. The descriptive statistics shows the mean of ROA_t, ROE_t and PM_t are 0.05, 0.09 and 0.05 respectively. This shows that ROE_t has an increment of 0.04 compare to ROA_t and PM_t throughout the year of 2006 till 2010. The median also shows that $\mathrm{ROE} \_t$ has the highest median which is 0.08 while both ROA_t and PM_t have a median of 0.05 . The maximum amount of ROA_t, ROE_t and PM_t are $0.58,2.12$ and 2.70 respectively while the minimum amount of ROA_t ROE_t and PM_t are $-0.42,-0.91$ and -2.51 respectively. The maximum and minimum amount shows that PM_t have the highest and lowest number in value. In addition, PM_t also shows the highest standard deviation which is 0.258159 . This shows that PM_t has the highest variance among the three variables. ROA_t and ROE_t standard deviation are only 0.096823 and 0.243353 respectively.

Table 4.1: Descriptive Statistics

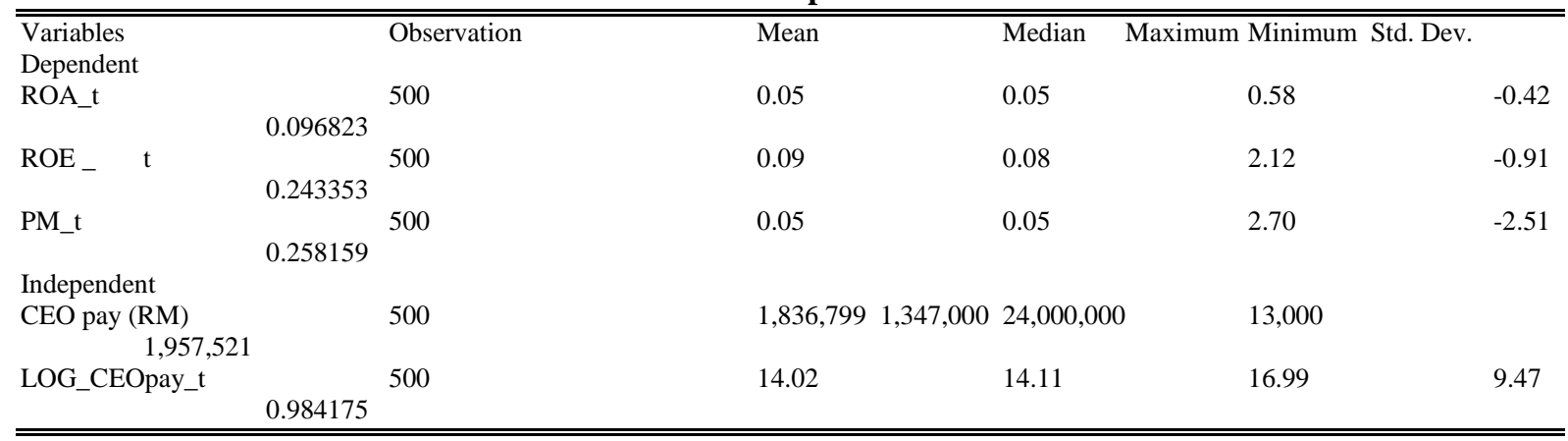

Note: CEO (chief executive officer) pay (RM) shows the amount of CEO pay in RM (Ringgit Malaysia) currency; LOG_CEOpay_t is the amount of CEO pay that was converted into log; ROA_t represents the return on assets; ROE_t represents the return on equity; PM_t refer to profit margin.

\section{Correlation Analysis}

The result of Pearson correlation analysis is reported in the following table. Pearson correlation analysis is used to check the correlation among ROE, ROA and profit margin (dependent variables) and CEO remuneration (independent variable). The absolute value of the correlation coefficient of $r= \pm 0.70$ shows of strong degree of linear relationship either in positive or negative sign. Thus, a correlation coefficient of zero $(r=$ 0.00 ) is indicated that the absence of a linear relationship and correlation coefficient of $r= \pm 1.00$ indicates a perfect linear relationship. 
Table 4.2 reports the bivariate statistical correlations for the 100 consumer product sector data we collected in Bursa Malaysia for the period 2006 to 2010. It is found that there is a significant positive relationship between CEO pay and ROA, ROE and profit margin. The relationship between CEO pay with ROA and CEO pay with ROE show a moderate positive relationship with correlation coefficient of $r=0.344$ and $r=0.311$ respectively. However, the relationship between CEO pay and profit margin shows a weak positive relationship with correlation coefficient of $r=0.081$.

Table 4.2 Correlation Analysis

\begin{tabular}{|c|c|c|c|c|c|c|}
\hline Variables & Observation & CEO Pay & ROE & ROA & Profit Margin & Significance \\
\hline \multicolumn{7}{|l|}{ Independent } \\
\hline$\beta$ LOG(CEO_PAY)t & 500 & 1 & $0.311^{* *}$ & $0.344 * *$ & $0.081 *$ & \\
\hline \multicolumn{7}{|l|}{ Dependent } \\
\hline ROE_t & 500 & $0.311^{* *}$ & 1 & $0.878^{* *}$ & $0.336^{* *}$ & 0.000 \\
\hline ROA_t & 500 & $0.344 * *$ & $0.878^{* *}$ & 1 & $0.511^{* *}$ & 0.000 \\
\hline PM_t & 500 & $0.081 *$ & $0.336^{* *}$ & $0.551^{* *}$ & 1 & 0.070 \\
\hline
\end{tabular}

**. Correlation is significant at the 0.05 level (2tailed).

*. Correlation is significant at the 0.1 level (2tailed).

\section{Coefficient Regression Analysis}

In this section there are 3 main dependent variables and 1 independent variable will be tested, (i) relationship between ROA and CEO pay; (ii) relationship between ROE and CEO pay; and (iii) relationship between PM and CEO pay. Table 4.3.1, table 4.3.2 and table 4.3.3 is the full model of regression that are used to test our Hypothesis 1, Hypothesis 2 and Hypothesis 3. Besides that, the superscripts **, and * denote the 5\%, and $10 \%$ levels of significance in regression respectively.

\section{Regression Analysis for Equation 1}

Table 4.3.1: Regression Analysis for Equation 1

Dependent Variable $=$ ROA_t

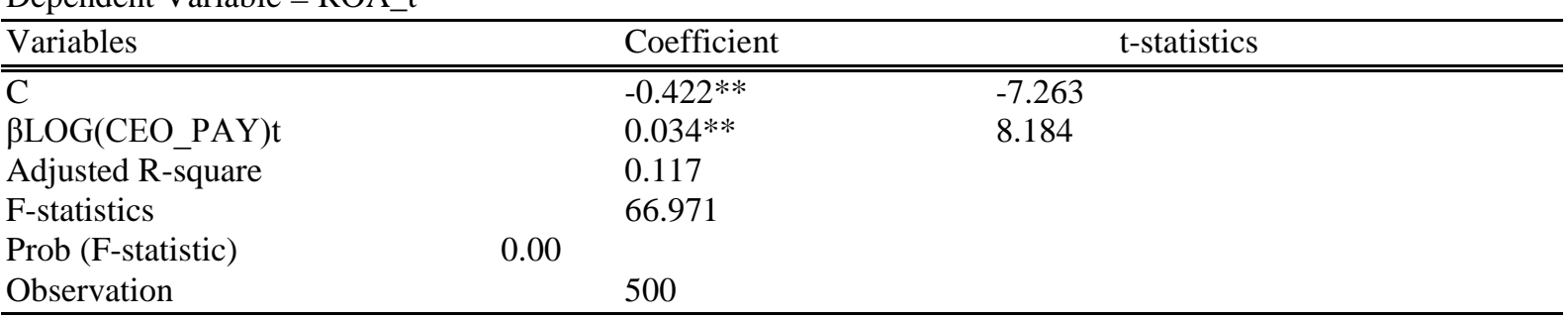

** $\quad$ Significant level at $\mathrm{p}<0.05$

* $\quad$ Significant level at $\mathrm{p}<0.1$

The regression analysis results in table 4.3.1 shows that there is a strong positive relationship between director remuneration and firm performance. The measurement is done by taking ROA_t as a dependent variable and LOG_CEOpay_t as an independent variable. The t-statistics for the slope was significant at the 0.05 critical alpha level, $\mathrm{t}=8.184, \mathrm{p}<0.05$. Therefore, in hypothesis 1 , we reject $\mathrm{H}_{0}$ and accept $\mathrm{H}_{\mathrm{a}}$. In conclusion, there is a positive significant relationship between ROA and CEO pay. Moreover, $11.7 \%$ of the variability in ROE could be explained by CEO pay. The positive relationship between CEO pay and ROA is consistent with the findings that was done by previous study (Core et al., 1999; Merhebi et al., 2006; Kato and Kubo, 2006). 


\section{Regression Analysis for Equation 2}

Table 4.3.2: Regression Analysis for Equation 2

Dependent Variable $=$ ROE_t

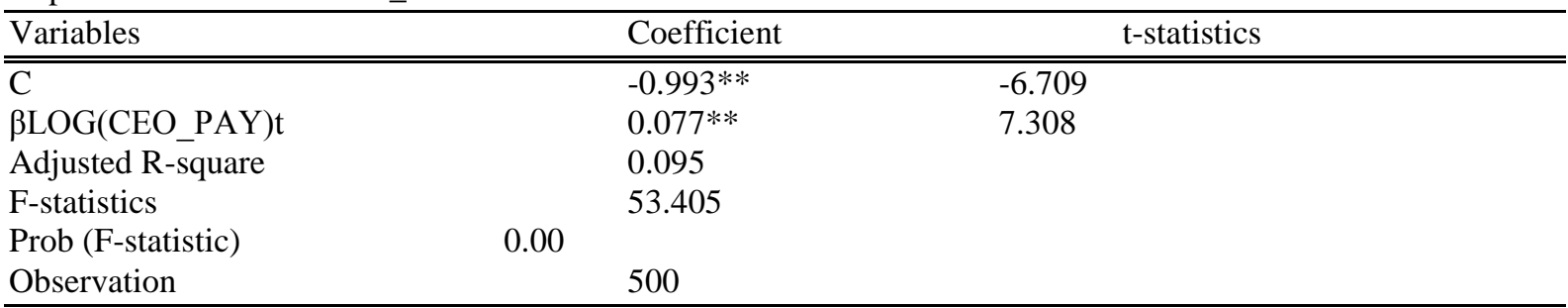

** $\quad$ Significant level at $\mathrm{p}<0.05$

* $\quad$ Significant level at $\mathrm{p}<0.1$

A simple regression was performed on 5 years with 100 companies of data to determine if there was a significant relationship between ROE and CEO pay. The t-statistics for the slope was significant at the 0.05 critical alpha level, $\mathrm{t}=7.308, \mathrm{p}<0.05$ (Table 4.3.2). Thus, in hypothesis 2 , we reject $\mathrm{H}_{0}$ and accept $\mathrm{H}_{\mathrm{a}}$. We conclude that there is a positive significant relationship between ROE and CEO pay. Furthermore, 9.5\% of the variability in ROE could be explained by CEO pay. In addition, Sigler (2011) had done a similar study with a sample of 280 firms that are listed in New York Stock Exchange (NYSE) from the period of 2006 till 2009. His study also shows a positive relationship between ROE and CEO pay.

\section{Regression Analysis for Equation 3}

Table 4.3.3: Regression analysis for Equation 3

Dependent Variable $=$ PM_t

\begin{tabular}{|c|c|c|c|}
\hline Variables & & Coefficient & t-statistics \\
\hline$\overline{\overline{\mathrm{C}}}$ & & $-0.245^{*}$ & -1.491 \\
\hline$\beta \mathrm{LOG}\left(\mathrm{CEO} \_\mathrm{PAY}\right) \mathrm{t}$ & & $0.021 *$ & 1.816 \\
\hline Adjusted R-square & & 0.005 & \\
\hline F-statistics & & 3.296 & \\
\hline Prob (F-statistic) & 0.070 & & \\
\hline Observation & & 500 & \\
\hline
\end{tabular}

** $\quad$ Significant level at $\mathrm{p}<0.05$

* $\quad$ Significant level at $\mathrm{p}<0.1$

This simple regression in table 4.3.3 was performed on 5 years with 100 companies of data to determine if there was a significant relationship between profit margin and CEO pay. The t-statistics for the slope was significant at the 0.1 critical alpha level, $\mathrm{t}=1.816, \mathrm{p}=0.07$. We conclude that there is a weak positive significant relationship between profit margin and CEO pay. Furthermore, $0.5 \%$ of the variability in profit margin could be explained by CEO pay. There are still a slight positive relationship among these two variables. A study that has been done before shows a similar results to our study which indicates that there is a relationship between profit margin and CEO pay (Mohammed and Nulla, 2012). Hence, in hypothesis 3, we reject $\mathrm{H}_{0}$ and accept $\mathrm{H}_{\mathrm{a}}$.

\section{Conclusion}

Agency problem existed when there is a conflict between the top management and their own shareholders. As corporate governance literature suggested, this conflict can be lessened through a remuneration packages that is provided to the management. By doing this, top management are more effective in running their company to make a better profit and guarantee a return to their shareholders.

CEO pay and firm performance play a big role in every company and there are lots of researches and studies emphasize a strong positive relationship between CEO pay and firm performance. As it is mentioned earlier, most of the studies that had been done before show a positive relationship between firm performance and CEO pay by using CEO pay as their dependent variable and firm performance as their independent variable. In our case, we switch the dependent and independent variable in another way round which is firm performance as our dependent and CEO pay as our independent variable. From the result that we got, we had come to a conclusion that the study we did show a similar result to those of other researchers did in other similar studies.

Based on the 100 samples of consumer product companies from 2006 till 2010 taken from Bursa Malaysia, there are three stages of relationship that we had analyzed. Firstly, the relationship between return on asset (ROA) and 
CEO pay. Subsequently is the relationship between return on equity (ROE) and CEO pay. Lastly, the relationship between profit margin and CEO pay. Besides that, the results were tested by using Pearson correlation and regression analysis. Based on the results that we obtained, there were 3 results and findings that can be discussed as follows.

We found that ROA and CEO pay seem to have a significant relationship based on the result and finding that was done. This shows that when ROA of firm increases then CEO pay as well will increase. The significant amount that was shown in correlation and regression analysis shows the same results. Whereas the coefficient regression and Pearson correlation shows a positive results. Therefore, in our first hypothesis, we accepted $\mathrm{H}_{\mathrm{a}}$ and rejected $\mathrm{H}_{0}$.

Secondly, further analysis was done again to test the relationship between ROE and CEO pay. $9.5 \%$ of the variability in ROE could be explained by CEO pay. The results also was supported by previous researchers that had done this study before. Thus, in hypothesis 2 we rejected $\mathrm{H}_{0}$ and accepted $\mathrm{H}_{\mathrm{a}}$ again.

Last but not least, we found that there are least of study that had done research on profit margin and CEO pay before (Mohammed and Nulla, 2012). However, there are still a weak type of positive relationship between profit margin and CEO pay. The results show that profit margin has the least significance relationship compare to the other two variables. However, it still shows a positive relationship. Hence, in hypothesis 3 , we rejected $\mathrm{H}_{0}$ and accepted $\mathrm{H}_{\mathrm{a}}$.

In our results and findings, we can conclude that ROA and ROE would be a better approach to perform a study because it provides a significant positive relationship with CEO pay. Whereas for profit margin, it has a lesser approach compare to ROA and ROE. From the past studies such as Jensen and Murphy (1990), Mehran (1995), Blanchard, Lopez-de-Silanes and Shleifer (1994); and Betrand and Mullainathan (2001) indirectly demonstrated that there were a weak relationship between profit margin and CEO compensation and in fact, there were no direct study was even done previously. Hence, profit margin could not be a better approach to study with CEO pay.

Overall, in this study, we can conclude that there is a relationship between CEO pay and firm performance. Firms are willing to pay a high salary to their CEO in order to motivate them to work harder for the firms to increase their performance.

\section{Limitations of study}

Throughout the research, there are some limitations that we faced during our data collection process. Firstly, the lacking of availability data. Some firms do not have a proper annual report for a particular year where it is removed or no longer available to the public. Besides, some firms do not comply a certain standard of orders in sorting and reporting their annual reports though they still adhere with the generally accepted accounting principles (GAAP). Sometimes, different firms have different orders of arranging their annual report although they still have the same components such as statement of financial position, statement of comprehensive income and statement of cash flow. In some firms, they did not clearly specify the board of director into independent non-executive director and non-independent non-executive director. Moreover, some of the firms did not state out whether the director remuneration is consisted of executive or non-executive or both directors' remuneration.

\section{Recommendations of study}

In order to achieve better and accurate result for future research, suggestions are proposed. A test on larger model with different sectors might be able to reveal more interesting and overall results. The collection of data sample could be larger by increasing the sample and adding in various sectors such as technology, finance, industries and many more. The stratified sampling method can be used in each sectors to give equal opportunity to be selected for the future studies. By testing on larger amount of sample and more sectors, the result on the relationship between firm performance and CEO pay will be more accurate.

Lastly, besides CEO pay, there are many other variables that might affect firm performance which are not included in this research. For example, the changes in politics, government policies on tax sector, the quality of internal management system and many more. Studying more variables will have a better understanding on the factors that will affect firm performance. 


\section{Reference}

[1]. Abowd (1990). "Does Performance-Based Compensation Affect Subsequent Corporate Performance?". Industrial and Labor Relations Review 23, February, pp. 52-72.

[2]. Abowd, J.M. \& Kaplan, D.S. (1999). Executive compensation: Six questions that need answering. Journal of Economic Perspectives, 13, 4: 145-68.

[3]. Adams, R. B. (2012). "Governance and the financial crisis". International Review of Finance, Vol. 12 (1), pp. 7-38.

[4]. Agrawal and G. Mandelker (1987). "Managerial incentives and corporate financing and investment decisions". Journal of Finance 42, September, pp. 823-38.

[5]. Aggarwal R, Samwick A, (1999). Executive compensation, strategic competition, and relative performance evaluation: Theory and evidence. The Journal of Finance, 54: 1999-2043.

[6]. ASX. (2003). Principles of Good Corporate Governance and Best Practice Recommendations. Retrieved October 22, 2013 from http://www.nfcgindia.org/ASXRecommendationsonBestCorporateGovernancePractices.pdf

[7]. Baker, G. P., Jensen, M.C., and Murphy, K. J. (1988). "Compensation and Incentives: Practice and Theory". Journal of Finance, Vol. 43, pp.593-616.

[8]. Balachandran, S., Kogut, B., and Harnal, H. (2010). "The probability of default, excessive risk, and executive compensation: A study of financial services firms from 1995 to 2008". Working paper, Columbia Business School.

[9]. Basu, A., Lal, R., Srinivasan, V., \& Staelin, R. (1985). Sales-force Compensation Plans: An agency theoretic perspective. Marketing science, 4, 267-291.

[10]. Bathala, C. T and Rao, R. P., (1995). The Determinants of Board Composition: An Agency Theory Perspective. Managerial \& Decision Economics, 16, pp.59-69.

[11]. Bauer, R., Guenster, N. \& Otten, R. (2004). Empirical evidence on corporate governance in Europe: the effect on stock returns, firm value and performance. Journal of asset management, 5(2), 91-104.

[12]. Baumol, W. J. (1959). Business behavior, value and growth. New York: Macmillan.

[13]. Baumol, W. J. (1967). Macroeconomics of Unbalanced Growth: The Anatomy of Urban Crisis. The American Economic Review, Vol. 57, No. 3 (Jun., 1967), pp. 415-426.

[14]. Bebchuck, L.A. and Cohen, A. (2004). The Costs of Entrenched Boards. Working Paper. Harvard Law School.

[15]. Bebchuk, L. A., Cohen, A., and Spamann, H. (2010). "The wages of failure: Executive compensation at Bear Stearns and Lehman 2000-2008". Yale Journal of Regulation, Vol. 27, pp. 257-282.

[16]. Bebchuk, L.A. \& Fried, J. (2003). Executive compensation as an agency problem. Journal of Economic Perspectives, 17, 3: 71-92.

[17]. Bebchuk, L.A., \& Fried, J. A. (2004). Pay without performance. Boston: Harvard University Press.

[18]. Bebchuk, L. \& Grinstein, Y. (2005). The Growth of Executive Pay. Oxford Review of Economic Policy, Vol. 21, No. 2. Retrieved from: http://www.law.harvard.edu/faculty/bebchuk/pdfs/Bebchuk-Grinstein.Growth-of-Pay.pdf

[19]. Berle A. A., Means G. C., (1932). The Modern Corporation and Private Property. The Macmillan Company.

[20]. Bertrand, Marianno and Mullainathan, Sendhil (2001). 'Are CEO's Rewarded for Luck? The Ones Without Principals Are'. Quarterly Journal of Economics, pp. 901-932.

[21]. Blanchard, Olivier Jean, Lopez-de-Selanes, Florencio, and Shleifer, Andrei (1994). 'What do Firms do with Cash indfalls?' Journal of Financial Economics, Vol. 36 (3), pp. 337-360.

[22]. Bolton, P., Mehran, H., and Shapiro, J. (2011). "Executive compensation and risk-taking". Staff Reports No. 456, Federal Reserve Bank of New York.

[23]. Boschen, M. / Smith, R. (1995). You can pay me now and you can pay me later: The dynamic response of executive compensation to firm performance. Journal of Business 68, 4, 577-608.

[24]. Brickley, J. A., Coles, J. L. and Terry, R. L. (1994). Outside Directors \& the Adoption of Poison Pills. Journal of Financial Economics, 35, pp. 371-390.

[25]. Brick, I. E., O. Palmon, J. K. Wald, (2006). CEO compensation, director compensation and firm performance: Evidence of cronyism? Journal of corporate Finance, 12, 403-423.

[26]. Bruce, A., Buck, T., and Main, B. G. M. (2005), "Top executive remuneration: A view from Europe". Journal of Management Studies, 42 (7), pp. 1493-1506.

[27]. Byrd, J. W and Hickman, K. A. (1992). Do outside Directors Monitor Managers: Evidence form Tender Offer Birds. Journal of Financial Economics, 32(2), pp. 195-221.

[28]. Bursa Malaysia, (2013, June 5). Consumer Products. Star Newspaper, pp. B10.

[29]. Chesney, M., Stromberg, J., and Wagner, A. F. (2012), "Risk-taking incentives and losses in the financial crisis". Working paper, Swiss Finance Institute, Switzerland.

[30]. Chung, K. H., Wright, P. and Kedia, B. B. (2003). Corporate Governance \& Market Valuation of Capital \& R \& D Investment. Review of Financial Economics, 12, pp. 161-172.

[31]. Coleman, A. K and Biekpe, N., (2007). On the determinants of board size \& its composition: additional evidence from Ghana. Journal of Accounting \& Organizational Change, 3 (1), pp. 68-77.

[32]. Core, J. E., Holthausen, R. W., and Larcker, D. F., (1999). Corporate governance, chief executive officer compensation and firm performance. Journal of Financial Economic, 51, 371-406

[33]. Coughlin, A. T., \& Schmidt, R. M. (1985). Executive compensation, management turnover, and firm performance: an empirical examination. Journal of Accounting and Economics, 13, 43-66.

[34]. Dalton, D. R., Daily, C. M., Certo, S. T. and Roengpitya, R. (2003). Meta-Analyses of Financial Performance and Equity: Fusion or Confusion? The Academy of Management Journal Vol. 46, No. 1 (Feb., 2003), pp. 13-26.

[35]. Dalton, D. R., Daily, C. M., Ellstrand, A. E. \& Johnson, J. L. (1998). 'Meta-analytic Reviews of Board Composition, Leadership Structure, and Financial Performance'. Strategic Management Journal, vol. 19, no. 3, pp. $269-290$.

[36]. Demsetz, H. and Villalonga, B., (2001). Ownership structure \& corporate performance. Working Paper, UCLA.

[37]. Demski, J. \& Feltham, G. (1978). Economic Incentives in budgetary control systems. Accounting review, 53, 336-359.

[38]. Devers, C. E., Cannella, A. A., Reilly, G. P. and Yoder M. E. (2007). Executive Compensation: A Multidisciplinary Review of Recent Developments. Journal of Management. Volume33. No.6, pp.1016-1072.

[39]. Doucouliagos, H. Askary, S. \& Haman, J. (2007). 'Directors' remuneration and Performance in Australian Banking'. Journal compilation, vol. 15 , no. 6 .

[40]. Eccles, R. (1985). Transfer pricing as a problem of agency. In J. Pratt \& R. Zeckhauser (Eds.), Principals and agents: The structure of business (pp. 151-186). Boston: Harvard Business School Press.

[41]. Eisenhardt, K. (1985). Control: Organizational and economic approaches. Management science, 31, 134-149. 
[42]. Fahlenbrach, R., and Stulz, R. M. (2011). "Bank CEO Incentives and the credit risk”. Journal of Financial Economics, Vol. 99 (1), pp. 11-26.

[43]. Fama, E. (1980). Agency Problems and the Theory of the Firm. Journal of Political Economy, 88, $288-307$.

[44]. Felton, R. (2004). A new era in corporate governance. McKinsey Quarterly 2, 28-41.

[45]. Filatotchev, I., and Allcock, D. (2010). "Corporate governance and executive remuneration: A contingency approach", Academy of Management Perspectives, 24 (1), pp. 20-33.

[46]. Gani, L and Jermias, J., (2006). Investigating the effect of board independence on performance across different strategies. The International Journal of Accounting, 41 (5), pp. 295-314.

[47]. Gomez-Mejia, Luis R. (1994). Executive Compensation: A Reassessment and a Future Research Agenda. Research in Personnel and Human Resources Management, Vol. 12, pp. 161-222.

[48]. Haubrich, G. P., and Popova, I. (1998). "Executive compensation: A calibration approach". Economic Theory, Vol. 12 (3), pp.561581.

[49]. Haugen and L. Senbet (1981). "Resolving agency problems of external capital through options" Journal of Finance, June, pp. 62948 .

[50]. Hengartner, L. (2006). Explaining executive pay: The roles of managerial power and complexity. Publisher: Deutscher UniversitätsVerlag, Wiesbaden.

[51]. Hermalin, B and Weisbach, M., (1991). The effects of board composition \& direct incentives on firm performance. Financial Management, 20(4), pp. 101-112.

[52]. Hirschey, M., and Pappas, J.L. (1981). Regulatory and Life Cycle Influences of Managerial Incentives. Southern Economic Journal 48: 327-34.

[53]. Hossain, M. Cahan, S. F. and Adams, M. B. (2000). The investment opportunity set \& the voluntary use of outside directors: new zeal \& evidence. Accounting \& Business Research, 30(4), pp. 263-273.

[54]. Hutchinson, M., (2002). An analysis of the association between firms' investment opportunities, board composition, \& firm performance. Asia Pacific Journal of Accounting \& Economics, 9, pp. 17-39

[55]. Jensen, M., and Meckling, W. (1976). Theory of the firm: Managerial behavior, agency costs and ownership structure. /o«r/ja/ of Financial Economics 3 (4): 305-60.

[56]. Jensen, M. C., \& Murphy, K. J. (1990). Performance pay and top management incentives. Journal of Political Economy, 98, 225264.

[57]. Jensen, M., \& Roeback, R. (1983). The market for corporate control: Empirical evidence. Journal of Financial Economics, 11, 5-50.

[58]. Kato, T. and Long, C. (2004). Executive Compensation, Firm Performance, and Corporate Governance in China: Evidence from Firms Listed in the Shanghai and Shenzhen Stock Exchanges.

[59]. Kirkpatrick, G. (2009). The Corporate Governance Lessons from the Financial Crisis. Financial Market Trends, Pre-publication version for Vol. 2009/1.

[60]. Kosnik, R. (1987). Greenmail: A study in board performance in corporate governance. Administrative Science Quarterly, 32, 162185 .

[61]. Krivogorsky, V., (2006). Ownership, board structure, \& performance in continental Europe. The International Journal of Accounting, 41(7), pp. 176-197.

[62]. Krugman, P. 2002. The insider game. New York Times (July 12).

[63]. Larcker, D., Richardson, S. and Tuna, I. (2004). Does corporate governance really matter?. Working paper, The Wharton School.

[64]. Leonard, J. (1990). Executive pay and firm performance. Industrial and Labor Relations Review, 43: 13-29.

[65]. Lewellen, C. Loderer and Martin, K. (1987). "Executive compensation and executive incentive problems" Journal of Accounting and Economics 9, April, pp. 209-31.

[66]. Lewellen, C. Loderer, K. Martin and G. Blum (1992). "Executive Compensation and the performance of the firm". Managerial and Decision Economics 13, pp. 65-74.

[67]. Lubatkin, M. and Chatterjee, S. (1994). Extending modern portfolio theory into the domain of corporate diversification: Does it apply? Academy of Management Journal, 37, pp. 109-136.

[68]. Lee, C., Rosenstein, S., Rangan, N. and Davidson III, W. N., (1992). Board composition \& shareholder wealth: the case of management buyouts. Financial Management, 21, pp. 58-72.

[69]. McConnell, J., and Servaes, H. (1990). "Additional evidence on equity ownership and corporate value", Journal of Financial Economics, Vol. 27, pp. 595-612.

[70]. Mehran, H. (1992). 'Executive Incentive Plans, Corporate Control, and Capital Structure'. Journal of Financial and Quantitative Analysis, Col. 27, pp. 539-560.

[71]. Miller, M. H. and Rock, K. (1985). Dividen Policy under Asymmetric Information. The journal of finance, Vol.40, No. 4. (sep., 1985), pp. 1031-1051.

[72]. Mintzberg, H. (2009), "No more executive bonuses!", Business Insight: MIT Sloan Managament Review/The Wall Street Journal, R3, R6, November 30, 2009.

[73]. Mitnick, B. (1986). The theory of agency and organizational analysis. Unpublished working paper, University of Pittsburgh.

[74]. Murphy, K.J. (1985). Corporate performance and managerial remuneration: An empirical analysis. Journal of Accounting and Economics, 7, 1-3: 11-42.

[75]. Myers, S. C. and Majluf, N. S. (1984). Corporate Financing and Investment Decisions when Firms have Information that Investors do not have. Journal of Financial Economics 13187-221. North-Holland.

[76]. MyShare2u. (2011). Citigroup CEO Salary rises, Vikram Pandit, to U.S. \$ 1.75. Retrieved from: http://www.myshare2u.com/bursamalaysia/citigroup-ceo-salary-rises-vikram-pandit-to-u-s-1-75/Murphy, K. J. (1999). Executive compensation. In handbook of labor economics Vol. 3B, ed. O Ashenfelter, D Card, pp. 2485-563. Amsterdam: Elsevier/NorthHolland.

[77]. Nulla, and Mohammed, Y. (2012). Is accounting net profit margin a valid measure of CEO cash Compensation?: A Comparative analysis on NYSE and TSX/S\&P Indexes Companies. International Journal of Scientific \& Engineering Research Volume 3, Issue 9.

[78]. Ozkan, N. (2007). Do corporate governance mechanism influence CEO compensation? An empirical investigation of UK companies. Journal of Multinational Financial Management, 17, 349-364.

[79]. Ozkan, N. (2007). CEO pay-for-performance sensitivity and corporate governance: An empirical investigation of UK panel data. 145.

[80]. Palmrose, Z.-V., Scholz, S., (2004). The circumstances and legal consequences of non-GAAP reporting: Evidence from restatements. Contemporary Research 21, in press. 
[81]. Park, Y. W. and Shin, H. H., (2003). Board composition \& earning management in Canada. Journal of Corporate Finance, 185, pp. $1-27$.

[82]. Pearson, O. S., (2006). Corporate Governance and Non-Financial Reporting Fraud. Journal of Business and Economic Studies, Vol.12 (1), pp27-40.

[83]. Prevost, A. K., Rao, R. P. and Hossain, M., (2002). Determinants of board composition in New Zeal \&: a simultaneous equation approach. Journal of Empirical Finance, 9, pp. 373-397.

[84]. Ramsay, I., (2001). Ramsay Report. Independence of Australian company auditors: Review of current Australian requirements and proposals for reform. Retrieved from: http//www.treasury.gov.au.

[85]. Rosenstein, S., and Wyatt, J. (1990). "Outside directors, board independence and shareholder wealth", Journal of Financial Economics, Vol. 26, pp. 175-191.

[86]. Sarbanes, P., and M. Oxley. 2002. Sarbanes-Oxley Act of 2002. Washington, DC: U.S. Congress.

[87]. Shin, J.Y., and Seo, J. (2010). "Less Pay and More Sensitivity? Institutional Investor Heterogeneity and CEO Pay.” Forthcoming in Journal of Management.

[88]. Sigler, K. J. \& Haley, J. P. (1995). "CEO Pay and Company Performance". Managerial Finance, Vol. 21 Iss: 2, pp.31 - 41

[89]. Sigler, J. (2011). CEO Compensation and Company Performance. Business and Economics Journal, volume 11, 1-8. Retrieved from https://attachment.fbsbx.com/file_download.php?id=476249825776656\&eid=AStLAW-

E9adM5HnrzvKC0HKQfbgwuZHqO2DhRiVbR7D8GrJ-YXW-

R9bDR1FjJ71L2OE\&inline=1\&ext=1370418178\&hash=ASs54cKNJEjwz3-E

[90]. Simon, H. A. (1959). Theories of decision-making in economics and behavioral science. American Economic Review, 49, $253-283$.

[91]. Smyth, Boyes, W. J. and Peseau, D. E. (1975). Size, Growth, Profits, and Executive Compensation in the Large Corporation.

[92]. Spence, A. M., \& Zeckhauser, R. (1971). Insurance, Information and individual action. American Economic Review, 61, 380-387.

[93]. Watts, R. L. and Zimmerman, J. L. (1978). Towards A Positive Theory of Determination of Accounting Standards. The accounting review vol. L111, No. 1.

[94]. Weisbach, M. S., (1988). Outside directors \& CEO turnover. Journal of Financial Economics, 20, pp. 431-460.

[95]. White, H. (1985). Agency as control. In J. Pratt \& R. Zeckhauser (Eds.), Principals and agents: The structure of business (pp. 187214). Boston: Harvard Business School Press.

[96]. Williamson, O. E. (1964). The Economics of Discretionary Behavior: Managerial Objectives in a Theory of the Firm. American Economic Association.

[97]. Yatim, P. (2012). Boardroom Pay, Performance and Corporate Governance in Malaysia. The Business \& Management Review, Vol.2 Number 2.

[98]. Yermack, D. (1996). 'Higher Market Valuation of Companies with a Small Board of Directors's Journal of Financial Economics, vol. 40, no. 2, pp. 185-211.

[99]. Young, B., (2003). Corporate governance \& firm performance: is there a relationship? Ivey Business Journal Online, pp. 1-4. 